\title{
When Traumatic Stressors are Not Past, But Now: Psychosocial Treatment to Develop Resilience with Children and Youth Enduring Concurrent, Complex Trauma
}

\author{
Katherine Tyson McCrea Professor \\ Loyola University Chicago, ktyson@luc.edu \\ Deanna Guthrie \\ University of Wisconsin-Whitewater \\ Jeffrey Bulanda \\ Northeastern Illinois University \\ Follow this and additional works at: https://ecommons.luc.edu/socialwork_facpubs \\ Part of the Social Work Commons \\ Author Manuscript \\ This is a pre-publication author manuscript of the final, published article.
}

\section{Recommended Citation}

McCrea, Katherine Tyson Professor; Guthrie, Deanna; and Bulanda, Jeffrey. When Traumatic Stressors are Not Past, But Now: Psychosocial Treatment to Develop Resilience with Children and Youth Enduring Concurrent, Complex Trauma. Journal of Child \& Adolescent Trauma, 9, 1: 5-16, 2015. Retrieved from Loyola eCommons, Social Work: School of Social Work Faculty Publications and Other Works, http://dx.doi.org/10.1007/s40653-015-0060-1

This Article is brought to you for free and open access by the Faculty Publications and Other Works by Department at Loyola eCommons. It has been accepted for inclusion in Social Work: School of Social Work Faculty Publications and Other Works by an authorized administrator of Loyola eCommons. For more information, please contact ecommons@luc.edu.

\section{(c) (i) $\ominus$}

This work is licensed under a Creative Commons Attribution-Noncommercial-No Derivative Works 3.0 License. (C) Springer International Publishing 2015 


\title{
When Traumatic Stressors are not Past, But Now:
}

\section{Psychosocial Treatment to Develop Resilience with Children and Youth

\author{
Enduring Concurrent, Complex Trauma
}

\author{
Katherine Tyson McCrea, Ph.D., M.Div., L.C.S.W. \\ Loyola University Chicago \\ Deanna Guthrie, Ph.D., L.C.S.W. \\ University of Wisconsin-Whitewater \\ Jeffrey J. Bulanda, Ph.D., L.C.S.W. \\ Northeastern Illinois University
}

\section{Please refer to and cite the published version of this manuscript, as this is a prepublication version of the manuscript published in:}

\section{McCrea, Katherine, Guthrie, Deanna, and Bulanda, Jeffrey. (2016). "When Traumatic Stressors are Not Past, But Now: Psychosocial Treatment to Develop Resilience with Children and Youth Enduring Concurrent, Complex Trauma." Journal of Child \& Adolescent Trauma, vol. 9, no. 1, pp. 5-16.}

We are most grateful to our many funders, including the Gabe W. Miller Memorial Foundation, who partially supported the initial phase of the Empowering Counseling Program (K. Tyson McCrea, P.I.). In addition, we are most appreciative of the support of Jack C. Wall, Ph.D. (now Director of the Social Work Program at San Jose State University) and Professor Emerita Brenda Crawley, Ph.D. (School of Social Work, Loyola University Chicago), Elizabeth Coffman, Ph.D, Professor (School of Communications, Loyola University Chicago), for the multiple ways they supported our programs. We also deeply appreciate the schools that gave the program a home: Doolittle East, Donoghue Elementary School, Jackie Robinson Elementary School, and Reavis School. Most of all, we thank the Empowering Counseling Program youth, who gave us the privilege of their partnership, provided inspiration and a constant source of fulfillment. This paper is dedicated to the memory of Leroy Griffin, an all-too-brief member of SUHO, who was murdered on 12/21/2013.

Contact information: Correspondence concerning this manuscript should be directed to Katherine Tyson McCrea, Ph.D., Loyola University Chicago School of Social Work, 820 N. Michigan Avenue, Chicago, Illinois,60611,ktyson@luc.edu, 312-915-7028.

Author bios:

Katherine Tyson McCrea, Ph.D., M.Div., L.C.S.W. is Professor at Loyola University Chicago School of Social Work, and the Principal Investigator of the Empowering Counseling Program.

Deanna Guthrie, Ph.D., L.C.S.W. is an Assistant Professor at the University of Wisconsin-Whitewater, Department of Social Work, and was a Director of the Empowering Counseling Program.

Jeffrey J. Bulanda, Ph.D., L.C.S.W., is an Assistant Professor in the Social Work Program at Northeastern Illinois University, and was a Director of the Empowering Counseling Program. 


\begin{abstract}
While providing school-based treatment for 450 urban impoverished children and youth from 2006-2014, we found implementing specific elements of PTSD treatment models reduced engagement and aggravated clients' symptoms. Clients' traumas were neither past nor singletype, but were multiple (complex) and unavoidably occurring concurrently with treatment, so we speculated that many trauma treatment elements needed revision to be effective. Using a participatory action research methodology, we developed a resilience-focused treatment model for concurrently-traumatized clients. Drawing from the strengths perspective, selfdetermination, and hope theories, key treatment elements revised here are triggers, re-enactment, avoidance, "silencing," and dissociation. Treatment guidelines include creating a safe zone, entering clients' worlds completely, frame flexibility, client self-determination of treatment agendas and duration, and pleasurable play.
\end{abstract}

Keywords: trauma treatment models, strengths perspective, impoverished children and youth, culturally-relevant services for African-American youth 


\section{When Traumatic Stressors are not Past, But Now: Psychosocial Treatment to Develop Resilience with Children and Youth Enduring Concurrent, Complex Trauma}

\section{Purpose}

Historically, trauma treatment models were developed in a context where the horrifyingly traumatic events were of one kind, and over before treatment began, such as a Veteran returning from war (Courtois \& Ford, 2009; Murray et al., 2013; Overbeek et al., 2013). But treatment for traumatic stress needs to add another modality, because a significant proportion of U.S. children and youth suffer from poverty (Reich, 2013) and live in deprived, violence-ridden communities, enduring trauma even while treatment goes on, causing risk for subsequent problems. For examples, currently one in five children and youth are poor and at much greater risk than their privileged peers for abuse and neglect, domestic violence, chronic hunger, community violence, and educational disadvantage (Future of Children, 2014; World Hunger Education Service, 2014). Twenty-one percent of low-income youngsters have mental health problems (Stagman \& Cooper, 2010). While mental health services should be provided in proportion to need, $75-80 \%$ of poor children who need mental health treatment do not receive it (National Center for Children in Poverty, 2013) for many reasons, including transportation obstacles, cost, stigma, clinicians' cultural insensitivity, and fear (Bigfoot \& Schmidt, 2010; Bringewatt \& Gershoff, 2010; Copeland, 2006; Fusick \& Bordeau, 2004).

For disadvantaged youngsters who do receive mental health care, traumas may not be over when treatment occurs, despite therapists' best efforts at protection. While supervising clinical social work services for 450 poverty-level, urban African-American children and adolescents from 2006-2014, we found it was necessary to revise traditional trauma treatment models to improve engagement and positive outcomes for concurrently-traumatized clients. The 
model is presented here to initiate dialogue about improving services for young clients who unavoidably suffer from diverse traumas concurrently with treatment.

To improve the accessibility and cultural relevance of services, the project reported here, called the Empowering Counseling Program (ECP, named by its student co-founders), has been carried out in community schools using participatory action (Bulanda \& Tyson McCrea, 2013; Bulanda, Szarzinski, Silar, \& Tyson McCrea, 2013; Tyson McCrea, 2012) and consumer evaluation designs (Davies et al., 2009; Macran, Ross, Hardy \& Shapiro, 1999; Tyson McCrea \& Spravka, 2008). Schools are increasingly seen as promising settings to improve equality in meeting young people's mental health needs (Armbruster \& Lichtman, 1999; Brown et al., 2006; Pynoos 1999; Sessions et al. 2001), because they eliminate many obstacles for clients, including transportation, poverty-level caregivers' demanding schedules, and stigma in attending psychiatric clinics (Banks et al. 1996; Fusick \& Bordeau, 2004; Washburn, 2002).

The syndrome of diverse, sustained traumas originating in childhood has been called developmental or complex trauma (Ford et al., 2013; Spinazzola et al., 2005; van der Kolk, 2005). Treatment models for complex trauma have considerable empirical support (the ITCT model [Briere \& Scott, 2006], the "attachment, self-regulation and competence" model [Kinniburgh et al., 2005], the integrative psychotherapy model [Lanktree \& Briere 2013], and child-parent psychotherapy [Lieberman 2005; Lieberman \& van Horn 2011]). But generally, the traumas are over for clients in complex trauma treatment research; so it remains essential to develop service models for clients traumatized concurrently with treatment.

\section{Background}

\section{Community needs}

Based on our research, stress on ECP clients resulting from community violence occurred in many forms. In one school, serving 675 impoverished preschool through $8^{\text {th }}$ graders, an average of one police report had to be made every day for illegal, in-school student activities; in one year 700 fights required intervention by staff, 1,000 students were suspended for 
disruptive behavior, and 150 families were reported for abuse and neglect (personal communication, principal, 2007). ECP clients reported sexual abuse that had gone unreported and/or unprosecuted, ranging from statutory rape of 13 year olds who then became teenage parents, to planned gang rape, to seductions into prostitution. ECP clients reported muggings, shootings, and gang intimidation. Six drive-by shootings in two weeks necessitated temporarily closing one school because bullets were flying into schoolroom windows. Further, following the shooting of an $8^{\text {th }}$ grader by his younger brother, students were devastated and ECP social workers spent days counseling students. Some school staff showed signs of vicarious trauma. Others were heroic, like the principal of one school who was successful at ending in-school beatings of children by their parents. Many parents were traumatized, resulting in short fuses and maladaptive parenting patterns. Some families responded cooperatively in trying to remedy their children's difficulties, yet other families ignored the problem; still, others aided and abetted their children's violence by coming to the school and inciting children to violence.

Nationwide, for the first time in years, rates of prosecuted child abuse and neglect are increasing (Finkelhor et al., 2013). In this context it is not surprising that tragically, every year ECP social workers had to report 5\%-15\% of the caregivers for child abuse or neglect. Typically, abuse reports were only investigated by public child welfare if the abuse left marks, occurred with an instrument, or included other elements such as medical neglect. Out of all the reports made by the ECP, including contacting public welfare officials at the highest levels of the organization, a child was never protected by removal from the home or intensive services to families. Reported abuse included infected cigarette burns, stomping on children, beating them with tree branches, sexual abuse, and threatening children with guns. Children reported their caregivers reacted to the abuse report and lack of protection by punishing them more harshly, deepening the children's despair, isolation, and anger. In addition to trying in every way possible to engage public child welfare, the only clinical solution was to help the children cope 
and activate their hope that they could make good choices and escape in the future. Hence, here we prioritize helping concurrently traumatized clients develop resilience.

\section{Theoretical Background: Defining resilience}

Ungar (2006) reports on the International Resilience Project (IRP), which has been studying resilience in children and adolescents in 14 communities around the world, using participatory action and mixed methods so as to maximize fidelity to diverse, culturally-specific constructs. According to the IRP, resilience is, "a multidimensional construct, the definition of which is negotiated (italics theirs) between individuals and their communities, with tendencies to display both homogeneity and heterogeneity across settings" (p. 219). Resilience has been defined as the ability to thrive despite adversity or, psychologically speaking, the capacity to experience trauma and loss, and yet sustain intact adaptive well-being (Sroufe, Carlson, Collins \& Egeland, 2005). Studies in diverse cultural contexts have found that children exposed to community stressors and poverty are resilient if they experience consistent loving support from their families (Garbarino \& Kostelny, 1996 Werner et al., 1968). These findings were confirmed more recently in a longitudinal study of human development with at-risk children (Sroufe et al., 2005). This study also demonstrated that social services build resilience by supporting parents'

and children's healthy attachment capabilities.

Two contemporary theories, Deci and Ryan's self-determination theory (2000; Ryan \& Deci, 2002, 2008), and Snyder's theory of hope (1994, 2002; Snyder et al., 1997), are especially relevant for deepening the understanding of how children acquire resilience in treatment. These theories focus on persons' subjective experience of intentionality and choice, and have a significant empirical base. Ryan and Deci (2008) define self-determination as an experience of 
inner freedom to pursue goals that one regards as being most important, satisfying, and vitalizing. In application to psychotherapy, self-determination theory proposes both a flexible (as opposed to manualized) process of treatment, and also that clients actively choose their treatment goals so they feel responsible for their change process (Ryan \& Deci, 2008). Also, self-determination theory explains why child-centered treatment, in which children co-create treatment contracts and goals, has such a powerful impact on children's motivation to change (Bratton, Ray, Rhine \& Jones, 2005; Landreth, 2012; Tyson McCrea, 2014). People are most motivated when they have the experience of being able to freely choose their goals (Ryan \& Deci, 2002, 2008). Three types of goals comprise the well-being of self-determination: competence, autonomy, and relatedness (Ryan \& Deci, 2008). Competence is a person's assessment of her/his capability to successfully complete a task, "a felt sense of confidence and effectance in action" (Ryan \& Deci, 2002, p. 7). Autonomy concerns perceived internal locus of control related to choices, acknowledgment of feelings, and opportunities for self-direction (Deci \& Ryan, 2000). Finally, relatedness refers to "feeling connected to others, to caring for and being cared for by those others, to having a sense of belongingness both with other individuals and with one's community" (Ryan \& Deci, 2002, p. 7).

The second theory relevant for understanding the development of children's resilience in treatment is Snyder's theory of hope $(1994,1997,2002)$. He defined hope "as the perceived capability to derive pathways to desired goals, and motivate oneself via agency thinking to use those pathways" (2002, p. 249). "Agency thinking" is a self-assessment of one's capacity to carry out the paths to goal attainment (Snyder, 2002). When one encounters obstacles, a conviction of 
agency creates motivation to generate alternative pathways (Snyder, 1994, as cited in Snyder, 2002). Hope also provides children with resilience, enabling them to believe they can achieve their goals in the face of adversity (Snyder, et al., 1997).

To foster resilience in the face of ongoing trauma, counseling fosters clients' autonomy, competence, and relatedness, and builds hope by supporting clients' pathways for achieving their goals and ability to achieve them (Guthrie, Ellison, Sami, \& Tyson McCrea, 2014; Tyson McCrea, 2014). Then, clients' internal working models of relationships become healthier; that is, organized, compassionate, pleasurable, affectionate, and calm. To develop resilience in the context of concurrent complex trauma, a treatment model with specific features was developed and is described further below.

\section{The Empowering Counseling Program's Background, Values and Assumptions}

\section{Program description}

The base for the complex trauma treatment guidelines described here is an eight-year partnership between a university School of Social Work and an impoverished African-American community in Chicago. The median income in the community was $\$ 25,215$, and $32.6 \%$ of the families qualified for food stamps/SNAP programs. Only $48 \%$ of the population was employed, and married partners comprised only $6.5 \%$ of the homes (U.S. Census, 2010). Residents of this community were six times more likely to die from domestic violence than those in Chicago as a whole (City of Chicago, 2007). Responding to the Empowering Counseling Program (ECP) survey about their wishes for social services, residents said they wanted assistance caring for youth and in preventing family and community violence. Parents were disturbed to the point of tears of frustration about poor public education, and wanted better social services for their youngsters. 
To respond to the residents' priorities, the Empowering Counseling Program was started in 2006. Since that time the ECP has served over 450 young people ages $4-18$ and educated 39 BSW, MSW, and Ph.D. social work students. Directed by a Professor with 30 years experience in clinical social work with disadvantaged children and youth, free services have been provided in a total of ten community schools by students under the supervision of experienced clinical social workers. Services are in two primary modalities: 1) school-based counseling for children and adolescents referred by teachers, school staff, or themselves, and 2) a school-based afterschool leadership program for youth (Stand Up! Help Out! or SUHO, see www. standuphelpout.org, Bulanda \& Tyson McCrea, 2013; Bulanda, Szarzynski, Silar \& Tyson McCrea, 2013; Guthrie, Ellison, Sami, \& Tyson McCrea, 2014), which provides adjunctive counseling for teenagers as needed.

When the ECP team implemented traditional trauma treatment model elements discussed here, symptoms were aggravated and client engagement reduced. As the team implemented the alternative treatment elements described below, those clinical results were evaluated according to whether they fostered client engagement and improved self-regulation. The model resulted in high client engagement and better outcomes than had been achieved using models for posttraumatic stress. The ECP's revised treatment guidelines reported below have consistently improved client engagement in treatment: By comparison with clinic attrition rates that can be 25-32\% (Lanktree et al., 1991), and higher in clinics serving poor youth (Kazdin, 2004), the attrition rate of children from the ECP services (e.g. those who stopped counseling services) was 0 . Termination of services occurred because the school year ended or the children's families moved away, not because young clients resisted help. Every year there has been a substantial waiting list of young clients. Many continued counseling over successive program cycles.

\section{Reasons for referral}

Most of the ECP counseling clients were referred by school staff or themselves for severe unhappiness, academic underachievement, disruptiveness, and fighting in school. 
Typically, half of the counseling clients resided with someone other than their birth parent; $30 \%$ reported suicidal ideation, and many lacked funds for public transportation, coats, food, and adequate heat. All had been exposed to community violence, primarily gun-related. Clients sought help with maltreatment from caregivers, feelings of loneliness and wanting friends, and feeling sad and angry with themselves and others. Most children older than $4^{\text {th }}$ grade were aware of and suffered due to racial discrimination, consistent with other findings ( Pachter \& Coll, 2009). As one youngster said, "my friend died and no one even reported it. If it had been a whale, it would have been all over the newspapers." Clients' symptoms included provoking fights and conflicts, learning problems, affect lability, and difficulty concentrating, remembering, and organizing activities. In individual and group sessions with social work interns, clients were preoccupied with fighting and self-defense, such as the kindergartner who brought a carving knife to school, saying he needed it "for protection."

\section{Diagnosis and assessment}

ECP assessments were comprehensive following a traditional clinical social work model. Interviews with children and families "started where the clients are," in a strength-based model, letting clients take the lead and empowering them from the first interaction (Saleebey, 2012). Over the course of several sessions the therapist developed a formulation of the presenting problems and history from the points of view of children, parents, school, and therapist; a developmental history of the child; a mental status exam of the client's functioning; a preliminary diagnostic judgment; short-term treatment goals; and long-term treatment goals.

Complex trauma as a nosology has yet to be included in the DSM-V (American Psychiatric Association, 2013). In the absence of one over-arching diagnosis, young people suffering from complex trauma tend to be given multiple diagnoses covering behavior disorders, learning disorders, incipient personality disorders, and various forms of psychosocial stress (Ford \& Courtois, 2013), making coordination of care difficult and aggravating stigma. It can be counterproductive to saddle children with the burden of negative categorizations, especially 
since, as Winnicott said, if one does one's job well as a therapist, symptoms will change and even disappear $(1982<1965>)$. With this in mind, ECP staff concluded that in an effort to be culturally sensitive, they would focus on supporting resilience rather than assigning potentially stigmatizing diagnoses. Accordingly, diagnostic judgments, while often useful for treatment planning, were kept in the therapists' personal notes and never made part of school or other records, unless they served the overall aims of advocacy for clients, such as emphasizing the children's needs for more supportive services at school.

\section{Revising traditional trauma treatment model concepts}

Treatment theories used by mental health providers have the following elements, which are addressed below: values, assumptions, concepts, principles, and guidelines. First, with regard to values, Judith Herman identifies three different roles in any trauma: Victim, perpetrator, and bystander (Herman 2013). For young people experiencing serious disadvantage and ongoing trauma, people who do not persistently help become bystanders. Lest the ECP staff be experienced as only “bystanders” to the youths' ongoing traumatization, it was essential to adopt a stance of persistent solidarity and advocacy to remedy the injustices the youth clients were experiencing.

Theoretical assumptions address ideas that are not provable or falsifiable based on evidence, but instead are chosen, especially the ontology (theory of reality) and epistemology (way of knowing that reality; Tyson, 1995). In concert with psychodynamic trauma theories and self-determination theory, our assumed ontology regarded the self as molded by and developing in the context of important relationships, especially parental and other caregiving relationships, such as relationships with therapists (Bulanda \& Tyson McCrea, 2013; Lanktree \& Briere, 2013; Pearlman \& Courtois, 2005). Traumatizing caregiving interferes with healthy social, emotional, and intellectual development, because it creates in the child disorganized internalized models of relationships (or working models, per Bowlby in Sroufe et al., 2005). Treatment aims to 
improve the internalized relationship models, self-esteem and social and intellectual competencies.

The best-validated family mental health service models, such as filial therapy (Bratton et al. 2005), theraplay (Booth, 2010), child-parent psychotherapy (Lieberman \& van Horn, 2011), and psycho-educational programs to prevent conduct disorders (Rones \& Hogwood, 2000) all require parental participation, which was often impossible for these parents who worked lowwage jobs, were pressured by caring for a disabled relative, or overwhelmed by substance abuse or other problems. Accordingly, while ECP consistently endeavored to serve families, most often the focus had to be on children and youth. The theoretical concepts of our model have been developed from concepts in child trauma treatment models that have been revised for clients suffering from concurrent, complex trauma. These are discussed below.

\section{Triggers}

Perceptual stimuli that resemble stored memories of traumatic events can function as "triggers." When "triggered," persons suffering from traumatic stress disorders re-experience emotions and thoughts associated with the traumatic events as though those events were reoccurring in the present, especially those contextual elements of the trauma situation that have the meaning of warning (Ehlers, Hackman, \& Michael, 2004). Characterized by the loss of present time perspective and intense flooding by experiences related to the trauma, the intrusive thoughts associated with being "triggered" can be crippling for clients. For youth in school, these moments of triggering severely interfere with the internalization and problem-solving necessary for learning (van der Kolk, 2005).

While clinicians can identifiably discriminate triggers from other ongoing life experiences when traumas are over, it is far more complicated in traumatizing contexts. At times, ECP clients were identifiably triggered. For instance, Keesha, who had been sexually abused by an uncle (no longer having any contact with her), became acutely distressed during a 
SUHO guest speaker's talk about date. She needed individual support from her social worker to work through the distress as the abuse events came flooding back into her mind.

In contrast, at other times, current traumas took center stage and were catalysts for processing both current and past traumas. For instance, on a fall afternoon Immanuel came to the SUHO program and sought support from his 30 peers and 3 instructors because he was horrified by helplessly watching a murdered friend die in from of him. As the "talking piece" went around the circle, many youth were "triggered" and started weeping, others reported having seen friends die of homicide or suicide, and some were terribly worried about relatives who were suicidal but lacked mental health care. Still others expressed a potentially toxic negative identity formation, "why do Black kids do this to each other?" The therapists reframed the problem as one of poverty and injustice, emphasizing that people of any color can become enraged when they experience such profound injustices, and that in fact any race that has survived centuries of holocaust has great strengths.

\section{Disclosure and denial}

When traumas are over, disclosure is initially uneven given clients' avoidance of distress associated with traumatic episodes. As the treatment alliance deepens, so does disclosure. For instance, Alexa, who had participated in SUHO for several years, was shot at a bus stop on her way to SUHO. The bullet grazed her scalp. Despite her tears and trembling, Alexa got on the bus and came immediately to SUHO. She made use of program supports, and was able to graduate high school and matriculate in a college far from the dangers of her childhood.

ECP clients seemed to regard hunger, physical suffering from inadequate medical care, repeated humiliation and rejection, and seeing friends or family suffer from untreated illness, hunger, and homelessness as everyday events not worthy of mentioning. For instance, on a cold winter day a social worker saw Ace, a teenager who was just suspended, come to the school office to say his home was miles away, he had no ride, and needed help to contact a caregiver. The staff member mocked him for being a "trouble-maker," to which Ace responded with 
silence. After calling Ace's home, the staff member abruptly hung up and glared at the boy without making any transportation arrangement. Ace, who had no coat and whose shoes had gaping holes, left quietly to walk home in the sub-freezing weather. The stunned social worker sought her supervisor to see what could be done, and the ECP then reached out to Ace, who disclosed that his sole caregiver was a homeless alcoholic. After several years of supportive counseling and participation in the youth program, he graduated from high school and matriculated in college. He said the counseling helped him realize the choices he made could create a better future (underscoring the importance of self-determination and hope).

The degree to which children could report everyday trauma varied with age. Specifically, younger children were more likely to complain to their social workers about being made to walk to school alone, being hungry and cold, or being frightened about how their caregivers treated each other. Older children, perhaps because they had become less trusting due to failures to protect them, typically required more extraordinary traumas before they would disclose everyday traumas. One client, Morris, said his gun-laden caregiver routinely remarked on killing people and engaged him in ongoing illegal activities. After another several months of counseling, Morris disclosed his father had physically attacked siblings, and he said the abuse had already been reported to public welfare multiple times by his school. He commented, "Child Services won't do anything about it, I don't want you to report it." Of course it had to be reported, and tragically, again, no child protection resulted from the report. Given the horrific trauma that was the fabric of his everyday life, Morris' ability to learn and succeed in school, seek out and sustain supportive relationships, and trust the social worker -- was remarkable.

To help teenagers share what they were going through, the after school youth program began to use a process of "letter-writing" (borrowing from Writers \& Gruell 1999). In this private and less personally confrontational context, the teens more readily disclosed the degrees and types of traumatic events they were experiencing than they could in their initial group or individual meetings with social workers. For some, the letters were cryptic but highly suggestive 
("Things go on in my home"), effective at alerting the social workers that youth needed help, but like a code, not disclosing specifics. The code allowed youth to evaluate the kind of response s/he was likely to receive and avoid the trauma of child welfare interviews that only led to more abuse.

\section{Re-enactment}

Re-enactments occur because, under stress, traumatized people find novel stimuli difficult and tend to engage in familiar relationship patterns (van der Kolk, 1989), even repetitive patterns of abuse or victimization. Under conditions of diverse, ongoing traumas, stressful situations are nearly continual. Re-enactments doubtless occur but are not so readily distinguishable from ongoing functioning as they are when clients with predominantly healthy coping re-enact single-type traumas that are over. For instance, is a youths' aggressive response to peers' fighting a re-enactment, or an effort at self-protection because s/he recognizes the peers might assault her/him next if s/he is perceived to be weak? Moreover, sometimes concurrently traumatized children's maladaptive behavior is their re-enactment in a safe context of motives they experienced in terrifying contexts but could express. For instance, Laticia's parents said she was extremely compliant at home. After a month at school, she was subject to sudden outbursts of extreme anger with teacher and peers, prompting her referral to the ECP. She told her social worker that she felt "angry all the time," and began to describe experiences of being humiliated, taunted, threatened, and terrorized by mother and step-father. Her outbursts were cries for help and also her desperate effort to save herself from directing the angry feelings in response to maltreatment against herself. It was not safe to rebel and assert her right to be heard and respected at home, but Laticia could do so at school and then have the relief of talking with her social worker about handling her disappointment and frustration.

Offering alternative, constructive ways to relate helped clients reflect about and forego re-enacting trauma. For example, when SUHO youth became mentors of community children, the youth learned non-coercive ways to respond to children's unwanted behavior. Many 
commented that they appreciated learning how to parent without "whipping" children (Bulanda \& Tyson McCrea, 2013).

\section{Avoidance and "silencing"}

Trauma treatment models typically include a symptom of PTSD, avoidance of stimuli that trigger distress. A context of ongoing trauma considerably complicates recognizing avoidance. For example, in one school threatened by multiple drive-by shootings resulting in the serious wounding of one youngster and the death of a recent alumnus, the children insisted they wanted to play basketball rather than discuss the events and their feelings about them. The youth, whose lives were dominated by fear of violence, needed times when they could feel safe, experience their competence and relationships without violence, and a refreshing, positive release of stress. Therefore, clients' desires not to discuss traumatic events and instead to engage in positive, playful experiences can be respected as an effort to develop peaceful and positive ways of coping, rather than regarded solely as avoidance.

Trauma perpetrators try to "silence" victims, whether the means are political (jailing or torturing dissenters), ethnically-based genocide (Lykes 1994), or familial (the threat of retaliation by caregivers if children report abuse). Young ECP clients were intimidated into silence in contexts of family and gang violence, and it was critical to help them voice their concerns in ways that did not jeopardize their safety, as noted previously. Currently traumatized clients who refuse to break the silence might not be avoiding, but trying to survive.

\section{Dissociation}

In trauma theory, dissociation has been described as resulting from two dynamics. First, it is a self-protective mechanism victims adopt in order to detach themselves from physical and psychological anguish (Herman, 2013), as when incest victims report they imagined they were out of their body and somewhere else during the abuse. Initially a voluntary and self-protective mechanism, when trauma is over victims report that dissociation is involuntary and feels so painful that victims self-injure to stop the numbness. Second, dissociation develops as 
individuals suffering from complex trauma repetitively experience disorganized, abusive relationships and distract themselves with disorganizing impulsivity to avoid resulting distress (van der Kolk, 1989). Both types of dissociation impair memory and learning.

The young ECP clients did not report the out-of-body form of dissociation, even those who described having been sexually abused when younger. However, the second form of dissociation -- learning problems and disorganized, chaotic reactions -- were very common. The youngsters' disorganized thinking reflected the disorganization in their environments and also served to distract them from their feelings about contemporary traumatic events. It was common for a child or teen to act out aggressively and then, upon questioning, to describe a very recent traumatic episode. For instance, an $8^{\text {th }}$ grader, Selina, was sent to the principal's office and then the social worker because she was alternately hostile and falling asleep in school. Only after the social worker allowed her to listen to music on the computer for 15 minutes did Selina disclose she had been up until 4 am because her family was fighting. She needed the social worker to connect her behavior with that event, and to help plan how she could ask for help if the family strife happened again.

\section{Principles and guidelines for constructive change}

A theory's principles postulate key causal processes. Treatment theories in particular contain principles or guidelines that promote positive client change. Following are alternative ECP guidelines that aim to facilitate the young clients' development of constructive inner relationship models, thereby also fostering the growth of adaptive capacities (Pearlman \& Courtois, 2005).

\section{A safe zone}

Several trauma treatment models (Ford et al. 2013) emphasize the critical importance for treatment of establishing the treatment relationship as a safe zone. Safety grows out of the therapist's reliability and positive regard, freedom from intimidation and shame-inducing communications, and respect for boundaries such as confidentiality. For ECP clients, providing 
necessary resources, such as food, clothing and shelter, connecting them with medical and dental care, advocating for clients to receive Individual Educational Plans and associated educational supports, and funding necessary transportation were also ingredients of creating a safe zone. In SUHO, safe zones were established in youths' relationships with each other, as SUHO youth walked home together to protect each other, comforted and advised each other and their child mentees about safety, and created a series of presentations and community forums affirming alternatives to violence.

\section{Empathic attunement: "Enter their world completely"}

The importance of the therapist's empathic attunement has been described extensively in self-psychological treatment models (Elson 1986; Kohut 1977), as part of healing "mindsight" (Siegel, 2001), in client-centered approaches to child treatment (Landreth, 2012), and filial therapy (Lieberman \& van Horn, 2011). The therapist's empathic attunement develops the client's natural capacities for self-regulation (Jordans et al., 2013; Lanktree \& Briere, 2013; Lieberman and van Horn, 2011; Perry, 2006). The ECP built on empathic attunement and developed a guideline termed "enter their world completely:" striving to hear the depth of clients' needs and understanding what they experienced as caring in a relationship, communicating to the children and youth their understanding of their struggles and strengths, empathizing consistently with their distress, and affirming their victories and strengths.

At times entering the clients' worlds meant altering the treatment frames and activities (with regard to intensive flexibility see also Lanktree \& Breire's [2013] concept of the therapeutic window; and Kinniburgh et al. 2005). Frame alterations included appointment times, as when a teenage girl was so pressured by her mother's negative comments about treatment that she was frightened about meeting with the counselor. When her therapist told her that she could choose when they would meet every week, the client responded by seeking out the therapist once weekly completely of her own accord. Modifications in traditional treatment planning also 
occurred when children and parents emphasized the importance of schoolwork, and social workers helped children with their homework during their sessions.

For example, rhe youngster mentioned previously, an $8^{\text {th }}$ grader named Selina, was so beset by fear of fighting that she was sharpening her teeth. Her only aspirations for herself were to be a "sideline ho" (a woman with whom a husband commits adultery). She refused to talk or play but did ask to listen to music she enjoyed on the school computer, and interacted with her therapist about the music. Eventually Selina began to trust and confide in her social worker, and it was counted a victory when she confided she hoped to be "precious to someone like your wife is to you."

Tuning in to clients' worlds is challenging in contexts of horrifying violence. Young clients recounted as factual experiences that seemed nightmarish. For instance, seven-year-old Queewon, who lived in a family where a male relative had "guns and kills people," described how his grandmother's eyeball fell out when she bumped into something, with sufficient detail that it seemed he must have seen it happen. When the social worker saw the grandmother wearing a patch over her eye, she had two possible interpretations of the boy's communication: 1) he might have seen the event, or 2) it was a 7-year-old's explanation of how his grandmother lost her eye, told with the fantasy spin of horrific violence characteristic of profoundly traumatized clients. Uncertain about what had actually occurred, the treatment moved forward with the understanding that this was exactly the client's world: nightmarish fantasy violence at times indistinguishable from what was actually happening around him. He reacted to his social worker's support with passionate attachment, taking pictures with her, coloring mementoes of their sessions he could refer to in class if he felt upset so he would not act out, safeguarding the chapstick she gave him, and expressing protectiveness towards her. His attachment was accompanied by gradually increasing self-regulation in the classroom. 


\section{Advancing client self-determination by allowing clients to lead treatment agendas}

The ECP team quickly found that if therapists took over the agenda of sessions as occurs in using "graduated exposure" to treat post-traumatic stress disorders (King et al., 2003), clients who were already forced to endure diverse, ever-present traumas become even more distressed, less regulated, and avoidant of treatment. Allowing children to set the treatment agenda following Gil's principle that child clients may "self-initiate" graduated exposure prevented those iatrogenic reactions and seemed to promote clients' self-regulation (Gil, 2010; Lanktree \& Briere, 2013). As mentioned previously, self-determination theory emphasizes that human wellbeing occurs as people can choose when and how to satisfy three primary types of aims: autonomy, relatedness, and competence (Ryan \& Deci, 2008). In a treatment context, this means the therapist keeps an eye on clients' wishes to fulfill those aims and allows clients to set the agendas of their treatment (for client-centered trauma treatment see also Gil [2010], [Kinniburgh et al. 2005]). This empowering approach resonates with the strengths perspective (Saleebey, 2012) and child-centered treatment approaches (Landreth, 2012), which have been consistently found to result in more constructive change than therapist-directed approaches to treatment (Bratton, 2005). Accordingly, children and youth determined the nature of the play or conversational activities, and therapists were careful to support the children's efforts at coping and developing self-regulation without imposing their agendas. The freedom clients had in setting the agenda of their sessions was also critical in making a space where they could disclose fresh traumas.

As children grow and change, the treatment goals they identify in concert with their therapists change (McCrea, 2014). Marcus began treatment at age 6 because he was chronically violent in school and had, at age three, killed family members by setting a fire, leading to his being ostracized by almost all his remaining family. He made a profound connection with his ECP social worker, calling her "the best social worker I've known in my life." Eventually, the twice-weekly sessions resulted in Marcus developing self-regulation over his intense aggressive 
acting-out. At the end of the year he confessed he would miss her terribly. When a new social worker started with him the following Fall, Marcus looked at her initially with some skepticism, but at the end of the first session said, "You'll be fine." During this second year of treatment he focused on academic success and peer relationships.

\section{Meaningful trauma narratives}

Many approaches to treatment underscore the value of helping clients create narratives of their trauma experiences, which foster integration of distressing and disorganizing experiences (Levy \& Wall, 2000; Siegel, 2001). In the ECP, the value of developing a narrative was included but subordinated to the overall principle of respecting clients' self-determination of the treatment agenda. For instance, there are some young clients who come readily for treatment, but neither play nor talk (Bonovitz, 2003). It was important not to further traumatize the ECP clients by causing them to feel like treatment failures. For example, Daniella was referred by her teacher because she would not talk in class. Her teacher also was concerned about Daniella's homelessness. Daniella clearly suffered from elective mutism and spent several sessions in complete silence and stillness. Then she started to cry, and when the therapist praised her for sharing her feelings, she began to communicate further by drawing a part-animal, part-human figure that lacked a mouth. Breaking the silence was made possible by the therapist's acceptance of her pace and preferred modes of communication.

Other clients on other occasions used narratives to advocate for themselves and their community. When SUHO youth were menaced by a series of drive-by shootings at the school, they were ardent in their wishes to remedy the violence, especially on behalf of their child mentees. They authored letters to President Obama about what it was like to be shot at, which they read at a community forum and sent to the White House. Since most of them had been shot at, and/or had friends, who had been shot and/or killed, their descriptions were graphic and powerful. Their audience gave them a standing ovation, creating deep affirmation for the youth. 


\section{Affirming client strengths and constructive coping}

Most of the street-wise teenage clients were aware of the pejorative academic and social stereotypes about them as only victims of disadvantaged circumstances. They described how such stereotypes were internalized, negatively altering their developing identities. For example, one client in the youth program wrote a poem about the dreadful jailing and murder of AfricanAmerican youth, eloquently affirming his effort to not become "a statistic," and that he hoped that if he was killed, "at least they will say [he] tried." To prevent aggravating stigma, it was essential to focus on and build client strengths, which is essential for resilience (Radigan \& Wang, 2011; Saleebey, 2012). In addition to the guidelines above, which implicitly reflect the strengths perspective, the ECP also applied the strengths perspective guidelines of: discerning, affirming and systematically supporting clients' specific strengths (defined as talents, resources, capacities, and knowledge); communicating belief in the clients, that they could find ways to cope with and surmount the obstacles they faced; helping clients free themselves from institutions and individuals who restrain and limit them (such as avoiding both police brutality and gang influence); and not accepting limiting conceptualizations of clients' capacities (such as what they could not accomplish academically, Saleebey, 2012).

\section{The therapeutic importance of healthy enjoyment}

Enabling young clients who have spent much of their lives in grim, miserable circumstances to thoroughly enjoy themselves with their therapist is essential to the therapeutic action (Barish, 2004; van der Kolk, 2005), and part of how the brain tries to heal itself after trauma (Perry, 2009). Accordingly, the ECP nurtured the young clients' experiences of constructive enjoyment, whether by letting them win games in play therapy, or planning a Scavenger Hunt with the youth program. A keen sense of humor was clearly a cultural strength of these young people, as were their enjoyments of activities such as music, dancing, and basketball. The social workers strove to be responsive both to the youths' suffering and also their need to experience as much healthy enjoyment as possible. Upbeat moments seemed to 
have, to the clients, the meaning that they were a pleasure to be with, affirming their self-worth. One young man said, when talking about being a mentor, that he wanted to play with his young mentee because he had suffered as a child when his overburdened family did not play with him (Tyson McCrea, 2012).

\section{Duration}

Most trauma-focused and client-centered treatment models for children and youth are designed to be carried out in a year at the most, although some researchers found treatment outcomes correlated positively with treatment duration (Lanktree \& Briere, 1995). Virtually all of the ECP counseling clients wanted help for longer than the social workers' nine-month internship could afford. Often they were seen by multiple social workers, participating in services for several years. Perhaps young clients experiencing concurrent, complex trauma perceive that they need ongoing care as a way to balance or compensate for the ongoing trauma.

\section{Conclusion}

While remediating poverty and disadvantage are "within our reach," (Schorr, 1997), unfortunately large numbers of children and youth continue to suffer from deepening income and educational inequalities (Reich, 2013), and the family and community stressors that accompany poverty. Untreated complex trauma overwhelmingly predisposes youth to school and relationship failures, destructive aggression, and conflict with the law (Silvern \& Griese, 2012). Potentially, treatments for complex, concurrent trauma can advance the welfare of children whose futures are jeopardized by multiple disadvantages.

We found that clients suffering from complex trauma in under-resourced communities, unavoidably traumatized concurrently with treatment, do not benefit from treatment guidelines developed for clients with single-type traumas that are over. Revised treatment guidelines are summarized in the following table:

Table 1: 
Summary Comparing Elements of Post-traumatic Stress Treatment Compared with Treatment for Concurrent Complex Trauma ${ }^{1}$

\begin{tabular}{|c|c|}
\hline $\begin{array}{l}\text { Customary trauma treatment elements for post } \\
\text { traumatic stress and complex trauma } \\
\text { that is over when treatment begins }\end{array}$ & $\begin{array}{l}\text { ECP treatment elements to build resilience with } \\
\text { clients suffering from complex trauma concurrently } \\
\text { with treatment }\end{array}$ \\
\hline $\begin{array}{ll}\text { TREATMENT } \\
\end{array}$ & GOAL \\
\hline $\begin{array}{l}\text { Mastering distress provoked by traumatic events, } \\
\text { overcoming trauma-related psychological symptoms, } \\
\text { and developing trauma-free identity }\end{array}$ & $\begin{array}{l}\text { Build resilience to ongoing trauma, comprised of self- } \\
\text { awareness of strengths, hope and self-determination }\end{array}$ \\
\hline UNDERSTANDING & SYMPTOMS \\
\hline $\begin{array}{l}\text { "Triggers" can be readily distinguished from ongoing } \\
\text { life experience and client self-awareness of them is } \\
\text { essential to coping with trauma }\end{array}$ & $\begin{array}{l}\text { "Triggers" are not readily differentiated from ongoing } \\
\text { life experience; some "everyday" traumas (e.g., hunger) } \\
\text { may not even function as triggers }\end{array}$ \\
\hline $\begin{array}{l}\text { Dissociation represents loss of memory and an out-of- } \\
\text { body self-awareness as an effort to cope with specific } \\
\text { traumatic events; it can be overcome through treatment }\end{array}$ & $\begin{array}{l}\text { Dissociation may occur; more often one sees profound } \\
\text { disorganization and preoccupation with current } \\
\text { traumatic events that makes attending to learning and } \\
\text { problem-solving difficult }\end{array}$ \\
\hline $\begin{array}{l}\text { Re-enactments express behavior and relationship } \\
\text { experiences acquired in previous trauma intruding into } \\
\text { contemporary functioning }\end{array}$ & $\begin{array}{l}\text { Re-enactments represent efforts at coping with past } \\
\text { trauma, but also comprise part of everyday functioning } \\
\text { under continual duress }\end{array}$ \\
\hline $\begin{array}{l}\text { Avoidance represents efforts to stave off distressing } \\
\text { memories of trauma; "Silencing" represents } \\
\text { internalization of directives from perpetrator of trauma; } \\
\text { Both are gradually overcome in treatment process }\end{array}$ & $\begin{array}{l}\text { Clients need respite from continual vigilance about } \\
\text { current and impending traumatic events; they need all } \\
\text { their psychological resources to cope with present } \\
\text { trauma and may continue to avoid memories of past } \\
\text { distress }\end{array}$ \\
\hline $\begin{array}{l}\text { Standardized scales may be used in assessment and for } \\
\text { evaluation of treatment }\end{array}$ & $\begin{array}{l}\text { All interviews directed by client's priorities; no } \\
\text { standardized scales }\end{array}$ \\
\hline $\begin{array}{l}\text { Diagnostic formulation essential for client's treatment } \\
\text { plan and sharing with family/school }\end{array}$ & $\begin{array}{l}\text { Diagnostic formulations kept in therapist's personal } \\
\text { notes for supervision only unless useful for advocacy }\end{array}$ \\
\hline TREATMENT & GUIDELINES \\
\hline $\begin{array}{l}\text { Client's environment is currently safe and there is little } \\
\text { need for sustained advocacy }\end{array}$ & $\begin{array}{l}\text { Clients' environment is fraught with danger and } \\
\text { disadvantage, so advocacy for client's protection and } \\
\text { well-being is a continual priority }\end{array}$ \\
\hline $\begin{array}{l}\text { Adults in the youths' environments commonly follow } \\
\text { through with basic social contracts to guarantee child } \\
\text { protection }\end{array}$ & $\begin{array}{l}\text { Systems delegated to protect children often do not, so } \\
\text { clients may be exposed to betrayals of trust as well as } \\
\text { trauma; therapist has to establish trustworthiness } \\
\text { through efforts to protect clients }\end{array}$ \\
\hline $\begin{array}{l}\text { Clients have sufficient resources (homes, food, } \\
\text { clothing, health care, reasonably good schools) so } \\
\text { practical assistance is not essential }\end{array}$ & $\begin{array}{l}\text { Clients and their families commonly need practical } \\
\text { assistance in the form of food, clothing, help with } \\
\text { housing, and support in obtaining best possible } \\
\text { education, health care, and other community resources }\end{array}$ \\
\hline $\begin{array}{l}\text { Clients have counselors and others available in school } \\
\text { and home to help them achieve steps towards } \\
\text { professional competence }\end{array}$ & $\begin{array}{l}\text { Disadvantaged clients lack supports and need therapist } \\
\text { to help them find pathways out of poverty, and plan } \\
\text { steps and choices to make that success possible }\end{array}$ \\
\hline $\begin{array}{l}\text { Many therapist values may direct treatment, from } \\
\text { neutrality to empathy }\end{array}$ & $\begin{array}{l}\text { Empathic attunement and solidarity are primary } \\
\text { therapist values, "Enter their world completely" }\end{array}$ \\
\hline $\begin{array}{l}\text { "Graduated exposure" in traditional trauma treatment } \\
\text { models }\end{array}$ & $\begin{array}{l}\text { Therapist encourages self-expression but does not } \\
\text { stimulate memories of trauma }\end{array}$ \\
\hline $\begin{array}{l}\text { Establishing treatment relationship as a safe zone } \\
\text { occurs primarily in the first phase of treatment }\end{array}$ & $\begin{array}{l}\text { Therapist's first priority is continually establishing } \\
\text { treatment relationship as "a safe zone," including as a } \\
\text { place where constructive pleasure occurs }\end{array}$ \\
\hline Develop trauma narratives & $\begin{array}{l}\text { Develop trauma narrative only when client-initiated; } \\
\text { facilitate awareness of past, present, future and future } \\
\text { goal formation (per Hope theory) }\end{array}$ \\
\hline
\end{tabular}

${ }^{1}$ Please see body of paper for relevant citations. 


\begin{tabular}{|l|l|}
\hline $\begin{array}{l}\text { Clients encouraged to focus on traumatic events using } \\
\text { verbal or play communications }\end{array}$ & $\begin{array}{l}\text { Clients communicate via letters, listening to music, } \\
\text { doing homework, as well as play therapy and verbal } \\
\text { expression }\end{array}$ \\
\hline $\begin{array}{l}\text { Treatment appointments and "frame" are stable and } \\
\text { protected }\end{array}$ & $\begin{array}{l}\text { Treatment frame may be altered to facilitate client } \\
\text { engagement }\end{array}$ \\
\hline $\begin{array}{l}\text { Overarching life goals are secondary priority to } \\
\text { mastery of trauma experience and resulting internalized } \\
\text { distress }\end{array}$ & $\begin{array}{l}\text { Therapist encourages client's self-expression of goals, } \\
\text { facilitates awareness of pathways to achieve them, and } \\
\text { self-efficacy about capacity for goal attainment }\end{array}$ \\
\hline Treatment duration determined by therapist and model & $\begin{array}{l}\text { Treatment duration determined by client; may be very } \\
\text { long-term }\end{array}$ \\
\hline
\end{tabular}

In the future, more research about effectively carrying out treatment for clients who suffer from concurrent, complex trauma will be important, especially in different contexts so that culturally-relevant principles can be developed. A participatory, partnership-based research approach that includes a strong emphasis on consumer evaluation is an essential element both to sustain engagement in treatment, and also to benefit from clients' expertise about meaningful change processes.

When offered a treatment model respectful of their priorities, ECP clients deeply valued the care of their social workers and participated readily. The young clients said that what they most valued in their services was feeling “cared for" (Bulanda \& Tyson McCrea, 2013; Guthrie, Ellison, Sami, \& Tyson McCrea, 2014), which gave them a conviction they were valuable and effective in the face of multiple experiences of denigration and helplessness. Being supported by their social workers when confronted with many obstacles helped them sustain and regenerate their hope (Guthrie, Ellison, Sami, \& Tyson McCrea, 2014). From these clients' perspectives, the cornerstone of resilience is feeling valued in a sustained, caring relationship. While it is challenging to provide therapeutic services for children and youth suffering from ongoing complex trauma in communities plagued with poverty and violence, it is most satisfying to know that the young clients regard the care as very worthwhile.

\section{References}


Disorders, 5th Edition. Arlington, VA, American Psychiatric Association.

Armbruster, P. and J. Lichtman (1999). Are school based mental health services

effective? Evidence from 36 inner city schools. Community Mental Health Journal, 35(6): $493-$ 504.

Banks, R., Hogue, Hogue, A., Timberlake,T., Liddle,H. (1996). An Afrocentric approach to group social skills training with inner-city African American adolescents. Journal of Negro Education.Special Issue: Educating children in a violent society, Part II: A focus on family and community violence, 65(4): 414-423.

Barish, K. (2004). What is therapeutic in child therapy? Psychoanalytic Psychology, $21(3), 385-401$.

BigFoot, D. S. and S. R. Schmidt (2010). Honoring children, mending the circle: cultural adaptation of trauma-focused cognitive-behavioral therapy for American Indian and Alaska Native children. Journal of Clinical Psychology, 66(8): 847-856.

Bonovitz, C. (2003). Treating children who do not play or talk: Finding a pathway to intersubjective relatedness. Psychoanalytic Psychology, 20(2): 315-328.

Booth, P. B. (2010). Theraplay: Helping parents and children build better relationships through attachment-based play (3rd ed.). San Francisco, Jossey Bass.

Bratton, S. C., Ray, D., Rhine, T., Jones, L. (2005). The Efficacy of Play Therapy With Children: A Meta-Analytic Review of Treatment Outcomes. Professional Psychology: Research and Practice, 36(4): 376-390.

Briere, J. \& Elliott, D. (1997). Psychological assessment of interpersonal victimization effects in adults and children. Psychotherapy, 34(4). 353-364.

Briere, J. and C. Scott (2006). Principles of Trauma Therapy: A Guide to Symptoms, Evaluation, and Treatment. Thousand Oaks, Sage.

Bringewatt, E. H. and E. T. Gershoff (2010). Falling through the cracks: Gaps and barriers in the mental health system for America's disadvantaged children. Children and Youth 
Services Review 32(10): 1291-1299.

Brown, E. J., McQuaid, J. McQuaid, J., Farina, L., Ali,R., Winnick-Gelles, A. (2006). Matching Interventions to Children's Mental Health Needs: Feasibility and Acceptability of a Pilot School-Based Trauma Intervention Program. Education \& Treatment of Children 29(2): 257-286.

Bulanda, J., Szarzynski, K., Silar, D., and McCrea, K. Tyson. (2013). "Keeping it Real”: An evaluation audit of five years of youth-led program evaluation. Smith College Studies in Social Work, 83: 2-3: 279-302. Doi: 10.1080/00377317.2013.802936.

Bulanda, J. and McCrea, K. Tyson. (2013). The promise of an accumulation of care: Disadvantaged African-American youths' perspectives about what makes an after school program meaningful. Child and Adolescent Social Work Journal, 30, 95-118. Doi: $10.1007 / \mathrm{s} 10560-012-0281-1$.

Chicago, City of (2007). Domestic violence crime trends: 2005. Chicago Police Department. At http://egov.cityofchicago.org:80/city/webportal/. Accessed 5/15/2007.

Child Trends Data Bank. (2014). Children's exposure to violence. http://www.childtrends.org/?indicators=childrens-exposure-to-violence. Accessed 10/4/2014.

Conradi, L., Kletzka, N. T. Oliver, T. (2010). A Clinician's Perspective on the Trauma Assessment Pathway (TAP) Model: A Case Study of One Clinician's Use of the TAP Model. Journal of Child \& Adolescent Trauma, 3(1): 40-57.

Copeland, V. C. (2006). Disparities in mental health service utilization among lowincome African-American adolescents: Closing the gap by enhancing practitioner's competence. Child and Adolescent Social Work Journal, 23(4): 407-431.

Courtois, C. and J. E. Ford (2009). Treating complex traumatic stress disorders: An evidence-based guide. New York, Guilford Press.

Davies, S. L., Horton, T. Williams, A.G., Martin, M.Y., Stewart, K.E. (2009). MOMS: formative evaluation and subsequent intervention for mothers living with HIV. AIDS Care 
21(5): 552-560.

Deci, E. L. \& Ryan, R. M. (2000). The 'what' and 'why' of goal pursuits: Human needs and the self-determination of behavior. Psychological Inquiry, 11(4), 227-268.

Ehlers, A., Hackmann, A., Michael., T. (2004). Intrusive re-experiencing in posttraumatic stress disorder: Phenomenology, theory and therapy. Memory 12: 403-415.

Elson, M. (1986). Self psychology in clinical social work. W.W. Norton. New York.

Finkelhor, D., L. Jones, Shattuck, A., Sato, K., (2013). Updated trends in child maltreatment, 2012. Crimes Against Children Research Center. Durham, N.H., University of New Hampshire.

Ford, J. and C. Courtois (2013). Treating complex stress disorders in children and adolescents: Scientific foundations and therapeutic models. New York, Guilford.

Ford, J., M. Blaustein, Habib, M., Kagan, R. (2013). Developmental trauma therapy models. In J. Ford and C. Courtois (Eds.). Treating complex traumatic stress disorders in children and adolescents: Scientific foundations and therapeutic models. New York, Guilford: 261-276.

Freedom Writers and E. Gruell (1999). Freedom Writers. New York, Broadway Books. Fusick, L. and Bordeau, W.C. (2004). Counseling at-risk Afro-American youth: An examination of contemporary issues and effective school-based strategies. Professional School Counseling, 8(2): 102-115.

Future of Children. (2014). http://www.princeton.edu/futureofchildren/index.xml. Accessed 10/6/2014.

Garbarino, J. and K. Kostelny (1996). The effects of political violence on Palestinian children's behavior problems: A risk accumulation model. Child Development 67: 33-45.

Gil, E. (2010). Children's self-initiated gradual exposure: The wonders of posttraumatic play and behavioral reenactments. Working with children to heal interpersonal trauma: The power of play. New York, Guilford: 44-63. 
Guthrie, D., Ellison, V., Sami, K., and McCrea, K. Tyson. (2014). Clients' hope arises from social workers' compassion: Young clients' perspectives on surmounting the obstacles of disadvantage. Families in Society 95 (2). Doi: 10.1606/1044-3894.2014.95.14.

Herman, J. (2013). Foreword. In C. Courtois and J. Ford (Eds.). Treating complex stress disorders (Adults): Scientific foundations and therapeutic models. New York, Guilford.

Jordans, M. J. D., Komproe, I. H., Tol, W. A., Nsereko, J., Jong, J. (2013). Treatment Processes of Counseling for Children in South Sudan: A Multiple $\mathrm{n}=1$ Design. Community Mental Health Journal 49(3): 354-367.

Jensen-Doss, A., Cusack, K. J., Arellano, M. (2007). Workshop-based Training in Trauma-focused CBT: An In-depth Analysis of Impact on Provider Practices. Community Mental Health Journal, 44(4): 227-244.

Kazdin, Alan. (2003). Psychotherapy for children and adolescents. In Bergin, A.E. and Garfield, S. L. (Eds.). Handbook of psychotherapy and behavior change, $4^{\text {th }}$ edition. (pp. 543589). New York: John Wiley and Sons, Inc.

King, N. J., Heyne, D., Tonge, B. J., Mullen, P., Myerson ,N., Rollings, S., and Ollendick, T. H. (2003). Sexually abused children suffering from post-traumatic stress disorder: Assessment and treatment strategies. Cognitive Behaviour Therapy, 32(1): 2-12.

Kinniburgh, K. J., Blaustein, M., Spinnazola, J., \& van der Kook, B. (2005). Attachment, self-regulation, and competency. Psychiatric Annals 35(5): 424-430.

Kohut, H. (1977). Restoration of the self. New York, International Universities Press.

Landreth, G. L. (2012). Play therapy: The art of the relationship (3rd ed.). New York, Taylor and Francis.

Lanktree, C. and J. Briere (2013). Integrative treatment of complex trauma. In J. Ford and C. Courtois (Eds.). Treating complex stress disorders in children and adolescents: Scientific foundations and therapeutic models. (pp.143-161). New York, Guilford.

Lanktree, C. B. and J. Briere (1995). Outcome of therapy for sexually abused children: a 
repeated measures study. Child Abuse and Neglect, 19(9): 1145-1155.

Levy, A. and J. Wall (2000). Children who have witnessed community homicide: Incorporating risk and resilience in clinical social work. Families in Society: The Journal of Contemporary Human Services, 81: 402-411.

Lieberman, A. (2005). Toward evidence-based treatment: Child-parent psychotherapy with preschoolers exposed to marital violence. Journal of American Academy Child and Adolescent Psychiatry, 44(12): 1241-1248.

Lieberman, A. and P. van Horn (2011). Psychotherapy with infants and young children: Repairing the effects of stress and trauma on early attachment. New York, Guilford.

Lykes, M. B. (1994). Terror, silencing, and children: International multidisciplinary collaboration with Guatemalan Maya communities, Center for Human Rights and International Justice. Center Affiliated Faculty Publications, Boston College: 1-22.

Macran, S., Ross, H. Hardy, G., Shapiro, D., (1999). The importance of considering clients' perspectives in psychotherapy research. Journal of Mental Health, 8(4): 325-337. McCrea, Katherine Tyson \& Spravka, Lesa. (2008). “I'm glad you asked”: Homeless persons diagnosed with severe mental illness evaluate their residential care. Journal of Sociology and Social Welfare, 35 (4):133-160.

McCrea, K. Tyson (2012). Choosing Compassion: How Severely Disadvantaged African-American Youth Prefer the Good. Vytautas Magnus University, Kaunas, Lithuania, June 18, 2012. Invited University-wide lecture. Available at: http://www.vdu.lt/lt/naujienos/socialinio-darbo-prof-k-tyson-mccrea-jav-paskaita.

McCrea, K. Tyson. (2014). "I'm a leader of all of them to tell the truth": Participatory action principles for uplifting research partners' identities. In Anita Gulczyńska and Mariusz Granosik (Eds.). Empowerment: Diagnosis - Reflection - Activity Orientations in Social Work. University of Lodz, Poland. WYG International Publications.

McCrea, K. Tyson. (2014). “'How does that itsy bitsy spider do it?’: Severely 
traumatized children's development of resilience in psychotherapy." Journal of Infant, Child and Adolescent Psychotherapy, 13 (2). 89-109. ID: 905319;

DOI:10.1080/15289168.2014.905319.

Murray, L. K., I. Familiar, Skavenski, S, Jere, E., Cohen, J., Imasiku, M., Mayeya, J., Bass, J.K., Bolton, P. (2013). An evaluation of trauma focused cognitive behavioral therapy for children in Zambia. Child Abuse and Neglect, 37(12): 1175-1185.

National Center for Children in Poverty. (2013). Basic facts about-low income children. http://www.nccp.org/publications/pub_1074.html. Accessed 10/4/2014.

Osterberg, L. D., A. Jensen-Doss, Cusack, K., Arellano, M. (2009). Diagnostic practices for traumatized youths: Do clinicians incorporate symptom scale results? Community Mental Health Journal, 45(6): 497-507.

Overbeek, M. M., de Schipper, J. Lamers-Winkelman, F., Schuengel, C.(2013). Effectiveness of specific factors in community-based intervention for child-witnesses of interparental violence: A randomized trial. Child Abuse and Neglect, 37(12): 1202-1214. Pachter, L. M. and Coll, G.C. (2009). Racism and child health: A Review of the literature and future directions. Journal of Developmental \& Behavioral Pediatrics, 30(3): 255263.

Parson, E. R. (1997). Posttraumatic child therapy (P-TCT): Assessment and treatment factors in clinical to catastrophic community violence. Journal Of Interpersonal Violence, 12(2): 172-194.

Pearlman, L. A. and C. A. Courtois (2005). Clinical applications of the attachment framework: Relational treatment of complex trauma. Journal of traumatic stress 18(5): 449-459.

Perry, B.D. (2009). Examining child maltreatment through a neurodevelopmental lens: Clinical applications of a neurosequential model of therapeutics. Journal of Loss and Trauma, 14(4), 240-255.

Pynoos, R. S. (1999). Dealing with tragedy and trauma in the school community: An 
overview.

http://www.nctsnet.org/nctsn_assets/pdfs/Overview_of_Trauma_in_School_Communities.pdf. Retrieved May 12, 2007.

Radigan, M. and R. Wang (2011). Relationships between youth and caregiver strengths and mental health outcomes in community-based public mental health services. Community Mental Health Journal, 49(5): 499-506.

Reich, Robert. (2013). Inequality for all: Documentary. At: http://inequalityforall.com/. Accessed 2/25/2014.

Rones, M. and K. Hogwood (2000). School-based mental health services: A research review. Clinical Child and Family Psychology Review, 3: 223-241.

Ryan, R. M. \& Deci, E. L. (2002). Overview of self-determination theory: An organismic dialectical perspective. In E. L. Deci \& R. M. Ryan (Eds.). Handbook of selfdetermination research. (pp. 3-33). Rochester, NY: University of Rochester Press.

Ryan, R. M. \& Deci, E. L. (2008). A self-determination theory approach to psychotherapy: The motivational basis for effective change. Canadian Psychology, 49, 186-193. DOI: $10.1037 / \mathrm{a} 0012753$.

Saleebey, D. (2012). The strengths perspective in social work practice: 5th edition. Needham Heights, MA, Allyn \& Bacon.

Schorr, L. B. (1997). Common Purpose: Strengthening Families and Neighborhoods to Rebuild America. New York, Anchor Books.

Sessions, P., Fanolis, V., Corwin, M. and Miller, J. (2001). Partners for success: A collaborative program between the Smith College School for Social Work and the Springfield, Massachusetts, public schools. Smith College Studies in Social Work, 71(2): 225-242.

Siegel, D. J. (2001). Toward an interpersonal neurobiology of the developing mind: Attachment relationships, 'mindsight,' and neural integration. Infant Mental Health Journal 22, (1-2): 67-94. 
Silvern, L. and Griese, B. (2012). Multiple types of child maltreatment, posttraumatic stress, dissociative symptoms, and reactive aggression among adolescent criminal offenders. Journal of Child \& Adolescent Trauma, 5(2): 88-101.

Snyder, C. R. (1994). The psychology of hope: You can get there from here. New York: Free Press.

Snyder, C. R. (2002). Hope theory: Rainbows in the mind. Psychological Inquiry, 13(4), 249-275. doi:10.1207/S15327965PLI1304_01.

Snyder, C. R., B. Hoza, W. E. Pelham, M. Rapoff, L. Ware, M. Danovsky. (1997). The development and validation of the children's hope scale. Journal of Pediatric Psychology, 22(3), 399-421. doi:10.1093/jpepsy/22.3.399

Spinazzola, J., Ford, J. D., Zucker,M., van der Kolk, B. A., Silva, S., Smith, S. F., Blaustein,M. (2005). Survey evaluates complex trauma exposure, outcome, and intervention among children and adolescents. Psychiatric Annals, 35(5): 433-439.

Sroufe, L. A., E. Carlson, Collins, W. A. Egeland, B. (2005). The development of the person: The Minnesota study of risk and adaptation from birth to adulthood. New York, Guilford.

Stagman, S. and Cooper, J. (2010). Children's mental health: What every policy-maker should know. National Center for Children in Poverty. http://www.nccp.org/publications/pub_929.html. Accessed 10/4/2014.

Stolbach, B. C. (1997)._The children's dissociative experiences scale and posttraumatic symptom inventory: Rationale, development, and validation of a self-report measure. (Doctoral Dissertation). University of Colorado.

Strand, V. and R. Abramovitz (2010). Core concepts in trauma treatment for children and adolescents. N. C. T. S. Network, National Center for Social Work Trauma Education and Workforce Development. 
Tyson, Katherine. (1995). New Foundations for Scientific Social and Behavioral

Research: The Heuristic Paradigm. Allyn \& Bacon: Needham Heights, MA.

U.S. Government Census. At: http://www.census.gov/2010census/. Accessed 3/15/2013.

Ungar, M. (2006). Resilience across cultures. British Journal of Social Work, 38(2): 218235.

van der Kolk, B. (2005). Developmental trauma disorder: Towards a rational diagnosis for children with complex trauma histories. Psychiatric Annals, 35(5): 401-408.

Van der Kolk, B.A. (1989). The compulsion to repeat the trauma. Re-enactment, revictimization, and masochism. Psychiatric Clinics of North America. 12(2): 389-411.

Washburn, J. J. (2002). Evaluation of a violence prevention program with low-income, urban African American youth. Dissertation Abstracts International: Section B: The Sciences and Engineering, 62(9-B): 4242.

Werner, E., J. Bierman, J., French, F.E., Simonian, K., Connor, A., Smith, R., Campbell, M. (1968). Reproductive and environmental casualties: A report of the 10-year follow-up of the Kauai Pregnancy Study. Pediatrics, 42: 112-127.

Winnicott, D. W. $(1982<1965>)$. The maturational processes and the facilitating environment: Studies in the theory of emotional development. New York, International Universities Press, Inc.

Wolpaw, J. M., Ford, J. D., Newman, E., Davis, J. and Briere, J. (2005). Trauma Symptom Checklist for Children. In T. Grisso, G. Vincent, and C. Seagrave (Eds.), Handbook of Mental Health Screening and Assessment for Juvenile Justice. (pp. 152-165). New York, Guilford.

World Hunger Education Service. (2014). Hunger in America: 2014 United States Poverty and Hunger Facts. http://www.worldhunger.org/articles/Learn/us_hunger_facts.htm. Accessed 10/4/2014. 
